\title{
Cartographic attribution of medieval Alan cities according to medieval written sources and archaeological research materials
}

\author{
Julia Treyman* \\ Don State Technical University, 344010, Rostov-on-Don, Russia
}

\begin{abstract}
This article is devoted to the study of the medieval Alania settlements in the X-XII centuries, mentioned in medieval written sources. The issue of territorial localization of the Alanian cities described in medieval texts is highlighted. A hypothesis according to which Alania was a union of four independent regions with cultural and political centers in the X-XII centuries is described. The first region (western region) occupied the territory of mountains and foothills in the gorges of the rivers Kuban, Teberda, Aksauta, Marukha, Maly Zelenchuk, Bolshoy Zelenchuk, Kyafar, Urup, Bolshaya Laba. The cultural and political center of the region was located on the territory of the Nizhne-Arkhyz settlement. The second area was located on the territory of the foothills in the valleys of the river. Kuma and R. Podkumka. This area is formed by a complex of settlements headed by the Rim-mountain settlement. The third region, headed by the Verkhne-Dzhulat settlement, existed on the river Tereke. The fourth region, formed by a complex of settlements headed by the Alkhan-Kalinsky settlement, was located on the river Sunzhe. The capital city of Maas, mentioned by the Arab traveler Al-Masudi, most likely existed on the territory of the western pro-Byzantine region of Alania in the area of the present Nizhne-Arkhyz settlement.
\end{abstract}

\section{Introduction}

There is very little information about Alanian cities in medieval written sources. Speaking about the possessions of the Alanian ruler, Al-Masudi writes: "The kingdom of the Alans represents an uninterrupted series of settlements so adjacent that when the roosters begin to crow, other roosters respond to them throughout the kingdom, thanks to the contiguity and, so to speak, the interlacing of farmsteads" [1]. Archaeologically, the settlement of the Alans is represented by a variety of lowland-foothill settlements and settlements, fortified by ditches and stone walls, with powerful cultural layers [2].

According to archaeological materials, the most intensive growth of settlements and cities dates back to the 10 th -12 th centuries. In the written sources of X-XII centuries there

\footnotetext{
*Corresponding author: treyman-17@yandex.ru
} 
are names of some Alanian cities (Maas, Dadakov, Fust, Dzhulat, Kasak, Allania, Askizia, Askala, Khaylan, Khaidak, etc.) [3]. Most of the listed cities do not have a generally accepted localization. The largest of the Alanian settlements investigated by archaeologists are Nizhne-Arkhyz, Rim-Gora, Upper Dzhulat, Alkhan-Kala. Attention should be paid to the geographical position of these cities. They are located in close proximity to the highways of the Great Silk Road. In addition, they all gravitate towards the foothills, that is, to the zones of the junction of mountains and plains. V.A. Kuznetsov explains this by the fact that these cities played the role of external and internal trade centers and connected the production areas of Alanya, where the mountainous regions specialized in metallurgy and cattle breeding, and the plains were engaged in agriculture [4]. Cartographic analysis showed that the aforementioned cities, in combination with smaller settlements, form four peculiar regions, evenly distributed over the territory of Alanya in the west-east direction.

\section{Discussion and results}

Most modern researchers believe that on the territory of Alania there were two ethnocultural groups that formed in the 5th - early 6th centuries: the Protodigorese (Asdigor) and the Protoiron (Irkhan), dividing it into western and eastern parts. The western part is localized in the upper reaches of the Kuban, Pyatigorye and modern Balkaria, the eastern part - in North Ossetia, Ingushetia and Chechnya. However, in the medieval written sources of the 10th century, there are references to the fact that Alania consisted of four tribes, one of which, called Dakhsas (Light Ases), had all the power and honor [5]. Taking the fact that the tribes mentioned probably had a territorial affiliation into consideration, it can be assumed that Alania in the X-XII centuries was an ethnic union, it was a union of four independent regions with the cultural and political centers identified above. The first region (western region) occupied the territory of mountains and foothills in the gorges of the rivers Kuban, Teberda, Aksauta, Marukha, Maly Zelenchuk, Bolshoy Zelenchuk, Kyafar, Urup, Bolshaya Laba. The cultural and political center of the region was located on the territory of the Nizhne-Arkhyz settlement. The second area was located on the foothills' territory in the valleys of the river Kuma and Podkumka. This area is formed by a complex of settlements headed by the Rim-mountain settlement. The third region, headed by the Verkhne-Dzhulat settlement, existed on the river. Tereke. The fourth region, formed by a complex of settlements headed by the Alkhan-Kalinsky settlement, was located on the river Sunzhe.

In the essay "Meadows of gold and mines of precious stones" the Arab traveler AlMasudi recorded that the capital of the country was called Maas [6]. For a long time, researchers have been dealing with the problem of localizing the capital of Alanya, since the text of Al-Masudi does not provide clear guidelines for determining its location.

K. Dosson placed it near the town of Mohachla on the river. Mishgike, a tributary of the river Cherek (territory of modern Kabardino-Balkaria). The modern toponymy of this republic is Mohachla and river Mishgik is not known.

According to the research by N.A. Karaulov and V.M. Minorsky Maas (Magas) should be sought in the territory of modern Checheno-Ingushetia. V.B. Vinogradov, conducting excavations at one of the largest Alan settlements of Checheno-Ingushetia - Alkhan-Kale, identified the Maas (Magas) with it [7]. At one time, V.A. Kuznetsov agreed with it: "In the light of the above considerations about the localization of the city of Magas on the territory of Checheno-Ingushetia, the hypothesis of V.B. Vinogradov deserves serious attention" [4]. The birth of the above-presented hypothesis was prompted by the passage of Al-Masudi: "The kingdom of the Alans borders (in the east) with the kingdom of Sarir (with the Dagestan Avars) ... The capital of the country is called Magas ... In this country there are also fortresses and lands located outside this city, where the king moves from time to time. 
At present, an agreement has been concluded between the king of the Alans and Sahib-as Sarir (the ruler of the Avars), and they mutually gave their sisters for each other" [1]. Since the description of the countries of the Caucasus by the Arab author is clearly from east to west, the mention of the Maas follows the description of the country of Sarir, and then political marriages between the dynasties of King Alan and King Sarir are reported, the researchers decided that the Maas should be sought on the eastern border of Alania. The most significant of the settlements in the eastern part of Alanya is Alkhan-Kala.

V.I. Markovin and Kh.D. Oshaev questioned the above-described hypothesis, ethnographer L.I. Lavrov, V.A. Kuznetsov spoke about the possibility of identifying the Maas with the Lower Arkhyz settlement [8]. Returning to the text of Al-Masudi, it follows: "After the proclamation of Islam in the reign of the Abbasid dynasty, the kings of the Alans adopted Christianity, and before that they were pagans. But after 320 (932), they turned away from Christianity and drove out the former bishops and priests, sent to them by the king of Rum" [1].

Analyzing this passage and comparing it with the previous ones, V.I. Markovin and Kh.D. Oshaev have come to the conclusion: "... if the inhabitants of Magas (Maas) were connected with Byzantium in their church affairs, it means that they were part of the Alan diocese," therefore Maas should be "somewhere to the west, outside of modern ChechenoIngushetia" [ 9].

V.A. Kuznetsov, having localized the center of the Alan metropolis on the territory of Nizhny Arkhyz and relying on the conclusion of V.I. Markovin and Kh.D. Oshaeva, concluded that "the Maas is Nizhny Arkhyz" [10].

Written sources report Christianization at the beginning of the 10th century as the ruling elite of Alanya. From this it follows that among the Alans, only the ruling dynasty in the person of the king and his family could contribute to the construction of Christian churches. Nizhne-Arkhyz settlement, dating from the X-XII centuries surpasses all Alanian cities in the number of Christian churches, including the Cathedral of Alania - the North Zelenchuk temple. It is sharply distinguished by the size and the presence of monuments of monumental architecture among other settlements known in the upper reaches of the Kuban (such as Adiyukh, Gilyach, etc.) [4]. According to V.V. Pishchulina, the ruling elite could give an order for the construction of the Cathedral in the capital of Alanya - the city of Maas (Magas) [11].

Attention should be paid to the meaning of the word Maas (Magas). According to the first option proposed by V.F. Minorsky, Maas means "Fly", which is quite a strange interpretation for the name of the capital city. Right there V.F. Minorsky makes an amendment and defines the Maas as "piety" [12]. Translated by N.A. Karaulova also, the word Maas is identified with "piety" [8]. According to Ibn Ruste, the entire population of the Alans was divided into four tribes, which, in turn, made up the four regions of Alania. Ibn Rusta reports: "... nobility and royal power belongs to the Dahsas tribe" [12]. According to most researchers, the Arabic Dakhsas is a distorted form of the Alanian Rukhs-As, which translates as Light Ases [6]. The name of the capital is Pious, that is, pleasing to God or righteous, consonant with the name of the tribe Light Ases. Therefore, the city with the center of the Alanian Metropolitanate could well be called Maas (Magas), which means Pious and thus be the capital of Alania, and the western region could be dominant in Alanya.

Attention is drawn to the geographical proximity of the Nizhne-Arkhyz settlement to Abkhazia and the Black Sea ports. It is located on one of the branches of the Darinsky route, leading along the Bolshoy Zelenchuk gorge through the Sancharo pass, further along the river Bzyb to Pitius. The shortest connection between Byzantium and Alania was carried out along this route through Abkhazia. The Byzantine writer Theophanes in the VIII century 
testifies that the Alans are neighbors with the Avazgs and therefore their "merchants now and then go to them" [13].

During the X-XI centuries Byzantine authors attest to the Alans' multiple visits to Byzantium. Michael Psellus reports that this happened "twice, or even three times a year" [1]. Among the archaeological finds of the Nizhne-Arkhyz settlement there are many imported things: painted Abkhaz ceramics, Byzantine glass, a coin of Constantine Porphyrogenitus in 945, a bronze cross with a Greek inscription in 1067, Byzantine stamped bronze and bone icons, a fragment from a Byzantine casket of the 10th -11 th centuries, Byzantine Eucharistic silver spoon, gold pectoral cross, etc. [4] In Nizhny Arkhyz, apparently, foreign merchants often appeared, and local merchants went to Abkhazia. Thanks to the above-described strengthening of the external relations due to trade relations, dynastic marriages and Christianization, here, like nowhere else, there is an intensive absorption of Byzantine culture by the Alans, ranging from the borrowing of household items to forms of architecture. V.A. Kuznetsov calls the Nizhne-Arkhyz settlement "an outpost of Byzantine influence in the North Caucasus" [10]. Byzantium made a lot of efforts to influence Alania through dynastic marriages and the policy of Christianization of the ruling Alan dynasty. It becomes quite logical that all efforts were directed specifically to the western region - dominant in the Alan kingdom and to the capital city of Maas (Magas).

In the work of Al-Masudi there are references to the impregnable fortress "Alan Gate". Another Arab author Ibn Rusta writes about this fortress in the essay "The Book of Precious Jewelery (Stones)" (Kitāb al-A'lāq al-nafisa [1] about this fortress are found in Armenian and Georgian sources [14]. Most researchers, headed by V.A.Kuznetsov, identify the "Alan Gates" with a fortress located in the Darial Gorge on the left bank of the Terek, at the confluence of the Kistinka River, in the south - the eastern borders of Alania [4]. In 1934, A.P. Kruglov discovered here the remains of a tower, powerful fortress walls and stone buildings on lime mortar, the remains of a water supply system, two walls blocking the road, etc. On a flat terrace to the south from the fortress there was a settlement with the remains of stone buildings [15]. According to the text of Ibn Ruste, to get to the fortress from the kingdom of the Dagestan Avars (bordering Alania in the east) requires nine days of travel (30 km per day) it was possible to go through the whole of Alanya and get off at its western borders. In addition, Ibn Rusta reports that the fortress is guarded by 1000 people from among its inhabitants. There was not such a populous settlement in the Darial Gorge and its environs. N. D. Kodzoev comes to the conclusion that we are talking about the NizhneArkhyz settlement, one of the large cities of Alania, located at its western borders, which could play the role of its "western gate". According to the author, the Nizhne-Arkhyz settlement cannot be identified with the "Alan Gate" fortress, since it is located in the river gorge, and according to the information of Al-Masudi and Ibn-Ruste, the fortress is located on the top of the mountain. More realistic is the idea that along the entire high-mountainous border of Alania, similar outposts, called the " Alan Gate", were placed [3]. One of them is located in Darial. Another is located at the western borders of Alanya on the Shpil mountain, at the confluence of the Kafara and Krivaya rivers.

According to V.A. Kuznetsov, the castle-fortress on Mount Spire could have been the residence of the Alanian ruler Durgulel and his ruling dynasty. This is indicated by the richest cemetery of the 11 th -12 th centuries located on the same mountain, which includes 11 unique dolmen-like crypts [16].

According to V.A. Kuznetsov, these 11 dolmens belong to the royal dynasty, and one of them is called the royal mausoleum of Durgulel. The castle is located on a flat mountain top, one of its defensive walls has an entrance gate, from which an ancient road goes down to the Kafar River. An ancient settlement associated with the castle was located at the foot of Mount Spiel. The castle was hidden in the depths of a wooded mountain range and at the 
same time had a good exit to the foothills along the valley of the river Kyafar (through modern village of Leso-Kefar and the station Sentorozhevaya). The castle was connected with the Nizhne-Arkhyz settlement by two mountain paths: one of them led to the Generovskaya glade (about $7 \mathrm{~km}$ above Nizhny Arkhyz), the second, crossing the Krivaya Balka through the abandoned Verkhnyaya Yermolovka, went to the area of Nizhnyaya Yermolovka village, where it was connected to the Zelenchuk gorge main road [10].

\section{Conclusion}

The mountain residence is located very close to the Nizhne-Arkhyz settlement. Archaeologically, it is dated to the X-XII centuries, and its buildings are similar in masonry technique to the residential buildings of the Nizhne-Arkhyz settlement [10]. In this regard, it is appropriate to recall the testimony of Al-Masudi that "The capital of the country is called Magas. In this country there are also fortresses and lands located outside this city, where the king moves from time to time" [1]. The fortress-castle on the Spire mountain could be one of those places outside the capital, where, according to Al-Masudi, the king moved to live [10]. The similarity of the above-described situation with the descriptions of Al-Masudi is another argument confirming the likelihood of identifying the Nizhne-Arkhyz settlement with the capital city of Maas (Magas).

The study was supported by the RFBR grant 19-012-00402 \21

\section{References}

1. A. Aleman, Alans in ancient and medieval written sources (Moscow, 2003)

2. E.P. Alekseeva, Ancient and medieval history of Karachay-Cherkessia. Ethnic and socio-economic development issues (Moscow 1971)

3. N. D. Kodzoev, Magas: according to archaeological and written sources (Magas, 2003)

4. V.A. Kuznetsov, Alania in the X-XIII centuries, Ordzhonikidze, 1971.

5. N. A. Karaulov, Collection of materials on the description of localities and tribes of the Caucasus, Tiflis 32, (1903)

6. Yu.S. Gagloyti, Electronic journal "Daryal" 1 (4), (1999) http://www.darialonline.ru/1999_1/soder.htm

7. V.B. Vinogradov, Historical and cultural interpretation of the Alkhan-Kalinsky settlement (Grozny, 1981)

8. N.A. Karaulov, Collection of materials on the description of localities and tribes of the Caucasus, Tiflis 38, (1908)

9. V.I. Markovin, Kh.D. Oshaev, Soviet archeology, Moscow 1, (1978)

10. V.A. Kuznetsov, Nizhniy Arkhyz in the X-XII centuries. On the history of the medieval cities of the North Caucasus (Stavropol, 1993)

11. V.V. Pishchulina, Christian temple architecture of the North Caucasus of the Middle Ages (Rostov-on-Don, 2006)

12. V.F. Minorsky, History of Shirvan Derbent in the X-XI centuries (Moscow, 1963)

13. S.G. Zeteishvili, Information about the Alans in the "Chronography" of Theophanes, The most ancient states on the territory of the USSR (Moscow, 1976) 
14. G. Ter-Mkrtchyan, M. Ter-Movsesyan, History of Shapukh Bagratuni, Echmiadzin, 1921

15. A.P. Kruglov, Soviet archeology, Moscow 3, (1937)

16. V.A. Kuznetsov, Brief reports of the Institute for the History of Material Culture, Moscow 76, (1956) 